\title{
Properties and stabilization of an extracellular $\alpha$-glucosidase from the extremely thermophilic archaebacteria Thermococcus strain AN1: enzyme activity at $1^{\circ} 0^{\circ} \mathrm{C}$
}

\author{
K.Piller, R.M. Daniel and H.H. Petach \\ Thermophile Unit, School of Science and Technology, \\ Waikato University, Hamilton, New Zealand
}

\begin{abstract}
An extracellular $\alpha$-glucosidase from the thermophilic archaebacterium Thermococcus strain AN1 was purified 875-fold in five steps (Hiload Q-Sepharose, phenyl Sepharose, HPHT-hydroxyapatite, gel filtration and Mono Q chromatography) with a yield of $4 \%$. It is a monomer with a molecular mass of about $130 \mathrm{kDa}$ and a $\mathrm{pI}$ around 5. At $98^{\circ} \mathrm{C}$, the purified enzyme in buffer has a half-life around $35 \mathrm{~min}$, which is increased to around $215 \mathrm{~min}$ in presence of $1 \%(\mathrm{w} / \mathrm{v})$ dithiothreitol and $1 \%(\mathrm{w} / \mathrm{v})$ BSA. Dithiothreitol $(1 \%,(\mathrm{w} / \mathrm{v}))$ and BSA $(0.4 \%,(\mathrm{w} / \mathrm{v}))$ also substantially increase the enzyme activity. The $K_{\mathrm{m}}$ at $75^{\circ} \mathrm{C}$ is $0.41 \mathrm{mM}$ with pNP- $\alpha-\mathrm{D}$-glucopyranoside as substrate. The substrate preference of the enzyme is pNP- $\alpha$-D-glucoside $>$ nigerose $>$ panose $>$ palatinose $>$ isomaltose $>$ maltose $>$ turanose, and no activity was found against starch, pullulan, amylose, maltotriose, maltotetraose, isomaltotriose, cellobiose and $\beta$-gentiobiose.

A variety of techniques including immobilization (eg. on epoxy and glass beads), chemical modification (cross and co-cross linking) and the use of additives (including polyols, BSA, salts, etc.) were applied to enhance stability at temperatures above $100^{\circ} \mathrm{C}$. The half-life could be increased from about 4 min at $110^{\circ} \mathrm{C}$ to $30-60$ $\min$ at $130^{\circ} \mathrm{C}$ in presence of $90 \%(\mathrm{w} / \mathrm{v})$ sorbitol, $1 \%(\mathrm{w} / \mathrm{v})$ dithiothreitol and $1 \%(\mathrm{w} / \mathrm{v})$ BSA, and by cocrosslinking with BSA in presence of $90 \%(\mathrm{w} / \mathrm{v})$ sorbitol. The stabilised enzyme showed good activity at $130^{\circ} \mathrm{C}$.
\end{abstract}




\section{Introduction}

Thermostable enzymes are of potential industrial importance and the upper limits of protein stability are of interest biochemically and in terms of the upper temperature limit for life. In this paper we have characterized a thermostable $\alpha$ glucosidase and attempted to further improve its stability above $100^{\circ} \mathrm{C}$.

$\alpha$-Glucosidases are produced by many thermophilic microbes $[1,2]$ and two types of activity of bacterial glucosidases have been reported: $\alpha$-D glucosidase (EC 3.2.1.20) and oligo-1,6 $\alpha$-glucosidase (EC 3.2.1.10) [3].

The $\alpha$-glucosidase described here is from Thermococcus strain AN1, an extremely thermophilic, sulphur reducing archaebacterium which was isolated from a geothermal spring in Rotorua, New Zealand [4,5].

A variety of methods are available for the stabilization of proteins [6-8], from amino acid substitution to the simple addition of non-specific stablising agents .

In the present paper we have investigated several simple and readily available techniques in an attempt to stabilize the enzyme against thermal inactivation at temperatures above $100^{\circ} \mathrm{C}$, with a view to investigating the upper limit of enzyme stability.

At these temperatures, in addition to conformational unfolding, degradative reactions such as deamidation, hydrolysis, cysteine elimination, peptide bond hydrolysis, etc. will be important. All these reactions need water, so salts and polyols, for example, which diminish water activity, should stabilize the enzyme. To prevent unfolding of the protein, immobilization to solid matrices was tested, with and without additives. Chemical modification using glutaraldehyde was carried out to form new linkages within and between enzyme molecules which should also help to prevent the unfolding. Interprotein crosslinking with BSA was also tested. 
Materials and Methods

\section{Growth of bacteria:}

Thermococcus strain AN1 was grown anaerobically under nitrogen without shaking in 2-litre Schott bottles as described by Hudson et al. [5], but the media contained $7 \mathrm{~g} / 1$ starch and $5 \mathrm{~g} / 1$ maltose. After 4 days incubation at $75^{\circ} \mathrm{C}$ cells from 100 litres medium were harvested using a hollow fibre filtration system (Amicon, Danvers, MA, U.S.A.). The supernatant was concentrated through an Amicon S10 Y10 (10kDa) cartridge to a total volume of 81 which was concentrated further through a PM 10 membrane to 1.61 .

\section{Purification of the $\alpha$-glucosidase:}

All column chromatography was carried out at room temperature. Fractions were concentrated and salt removed using Amicon PM 10 ultrafiltration membranes. The concentrated supernatant was applied in $400 \mathrm{ml}$ portions to a Hiload Q Sepharose 26/10 -column (10cm x 2.6cm; Pharmacia, Upsala, Sweden), equilibrated with $20 \mathrm{mM}$ bis Tris buffer, $\mathrm{pH} 6.3$. The $\alpha$-glucosidase activity was eluted at $0.3 \mathrm{M} \mathrm{NaCl}$ with a 560 $\mathrm{ml}$ linear $0-0.35 \mathrm{M}$ salt gradient in the same buffer (flow rate was $4 \mathrm{ml} / \mathrm{min}$ ). The pooled and active fractions were diluted in $0.1 \mathrm{M}$ sodium phosphate-buffer $\mathrm{pH} 6.8$ and applied to a Phenyl-Sepharose (low substitution) column (10 $\mathrm{cm} \times 5 \mathrm{~cm}$, Pharmacia). Activity was eluted with successive $200 \mathrm{ml}$ volumes of 10, 15, 20, 25, 30, 40 and $50 \%$ (v/v) ethyleneglycol. The ethyleneglycol was removed by repeated dilution with phosphate-buffer and ultrafiltration through PM10 Amicon membrane. Active fractions were applied to a Bio-Gel HPHT-hydroxyapatite chromatography column $(10 \mathrm{~cm} \times 0.78 \mathrm{~cm})$ and eluted using a $40 \mathrm{ml}$ linear phosphate gradient of $10-350 \mathrm{mM}$ sodium phosphate, $\mathrm{pH} 6.8$, at a flow rate of $0.5 \mathrm{ml} / \mathrm{min}$; the $\alpha$-glucosidase activity was eluted at about $30 \mathrm{mM}$ phosphate. Active fractions were concentrated through Centricon cells (10 kDa, Amicon) to $1 \mathrm{ml}$ and applied to a Superose P12 gel-filtration column $(50 \mathrm{~cm} \times 1.5 \mathrm{~cm}$, Pharmacia) equilibrated with $20 \mathrm{mM}$ sodium phosphate-buffer containing $0.2 \mathrm{M} \mathrm{NaCl}$, pH 6.8 (flow rate $0.2 \mathrm{ml} / \mathrm{min}$ ). The active fractions were finally applied to a Mono Q 5/5 (5cm x 1 cm, Pharmacia) anion-exchange column equilibrated 
with $20 \mathrm{mM}$ bis-Tris buffer, $\mathrm{pH}$ 5.9. Activity was eluted at $0.15 \mathrm{M} \mathrm{NaCl}$ with a $180 \mathrm{ml}$ linear $0-0.4 \mathrm{M}$ salt gradient at a flow rate of $0.6 \mathrm{ml} / \mathrm{min}$ into collection tubes containing $1 \mathrm{ml}$ of $0.2 \mathrm{M}$ sodium phosphate buffer, $\mathrm{pH} 7.4$, and $0.05 \%$ dithiothreitol.

For the stabilization studies enzyme preparations from the HPHT and Superose steps of the purification procedure were used.

\section{Enzyme assay:}

Activity was determined by measuring at $400 \mathrm{~nm}$ the pNP released from the pNP- $\alpha-\mathrm{D}$ glucopyranoside by the enzyme at $75^{\circ} \mathrm{C}$. The assay mixture, consisting of 4 $\mathrm{mM}$ substrate, $80 \mathrm{mM}$ Mes buffer, $\mathrm{pH}$ 6.3, or 0.16 M sodium-phosphate buffer, $\mathrm{pH} 7.4$, containing $0.04 \%(\mathrm{w} / \mathrm{v})$ dithiothreitol and enzyme, in a total volume of $0.5 \mathrm{ml}$, was incubated for an appropriate time at $75^{\circ} \mathrm{C}$. The reaction was stopped by addition of 1 $\mathrm{ml}$ of $1 \mathrm{M}$ sodium carbonate. One unit is defined as causing the release of $1 \mu \mathrm{mol}$ of $\mathrm{pNP} / \min$ (molar absorption coefficient of the substrate $\mathrm{pNP}=18500 \mathrm{~min}^{-1} \mathrm{M}^{-1}$ at 400 $\mathrm{nm})$.

\section{Analysis of degradation products}

Samples taken from assay mixtures were injected on to a h.p.l.c. Bio-Rad Aminex HPX-42A column. Filtered vacuum-degased water formed the mobile phase at a flow rate of $0.6 \mathrm{ml} / \mathrm{min}$, and a column temperature of $85^{\circ} \mathrm{C}$. The products were monitored with a refractive-index detector. Standards used were $20 \mathrm{mM}$ xylose, glucose, maltose, maltotriose, maltotetraose and maltohexaose, (standards and substrates were from Sigma, MO, USA). The substrate concentration was $40 \mathrm{mM}$ in sodium phosphate buffer, $\mathrm{pH} 7.4$, in the presence of $0.01 \%(\mathrm{w} / \mathrm{v})$ dithiothreitol, and 3.5 $\mathrm{mU}$ of enzyme used per assay.

\section{Thermostability determination}

For the experiments below $100^{\circ} \mathrm{C}$, the tests were carried out in eppendorf tubes fully immersed in the water during the incubation. For the experiments over $100^{\circ} \mathrm{C}$, the tests were carried out in autosample vials $(1.5 / 2 \mathrm{ml}$, Alltech) in an oil bath. At intervals, duplicate tubes or vials were removed, cooled rapidly and stored on ice for the subsequent assay at $75^{\circ} \mathrm{C}$. 
SDS-PAGE and determination of $\mathrm{pI}$

SDS-PAGE was performed on a Phast-System (Pharmacia) in a 10-15\% (w/v) gradient polyacrylamide gel. Standard markers LMW (Pharmacia) from 14400 - 94000 Da were used. The PAGE conditions were these indicated by Pharmacia. Gels were stained by the Bio-Rad (Richmond, U.S.A.) silver staining procedure.

Isoelectric focusing was performed on a Phast System in polyacrylamide gels containing Pharmalytes 2-10 as described by Pharmacia. Standards were supplied from Serva (Heidelberg, FRG).

\section{Stabilization techniques:}

\section{Cocrosslinking}

Porous protein particles were produced by aggregating proteins in the frozen state [10]: BSA $(180 \mu \mathrm{g})$, enzyme $(75 \mu \mathrm{l}$ of a $1 \mathrm{U} / \mathrm{ml}$ preparation), and glutaraldehyde (30 $\mu \mathrm{l}$ of a $50 \%$ solution) were mixed in $2.5 \mathrm{ml}$ sodium phosphate buffer $0.2 \mathrm{M}$, pH 7.4. After stirring, the mixture was incubated at $-20^{\circ} \mathrm{C}$ for 2 hours, followed by 3 hours at $4^{\circ} \mathrm{C}$. The sponge-like polymer was washed with $0.2 \mathrm{M}$ lysine and water and freeze-dried over night. The sponge-like polymer was homogenized to powder and $4 \mathrm{ml}$ phosphate buffer was added..

\section{Crosslinking $[11,12]$}

Enzyme ( $75 \mu 1$ of a $1 \mathrm{U} / \mathrm{ml}$ preparation) and glutaraldehyde solution $(50 \%, 200$ $\mu \mathrm{l})$ were stirred for 3 hours at room temperature in $2 \mathrm{ml} 0.2 \mathrm{M}$ sodium phosphate buffer, $\mathrm{pH}$ 7.4. The reaction mixture was then ultrafiltrated and diluted with buffer several times to remove the glutaraldehyde.

\section{Immobilization :}

Partially purified $\alpha$-glucosidase was immobilized onto controlled-pore glass beads (pore diameter: $50 \mathrm{~nm}, 104.9 \mathrm{~nm}$ and $11.5 \mathrm{~nm}$ with a particle size of $125-177 \mu, 80-$ $120 \mu$ and $80-120 \mu$, respectively from Sigma, St.Louis, MO, USA), and onto long chain alkylamine-coated glass beads (pore diameter $50 \mathrm{~nm}$, particle size 125-177 $\mu$ from Pierce, Rockford, USA; $0.33 \mathrm{~g}$ ) by the silane/glutaraldehyde coupling method [13 and 
14, respectively]; and onto epoxy-beads (VA-Epoxy Biosynth Carrier from Riedel-deHaen, Germany) [15] and oxirane acrylic beads (containing approx. $800 \mu$ mol of oxirane groups per g of solid $30 \mu \mathrm{m}$ macroprous particles, from Sigma) by the method of Solomon et al. [16] with following modifications: Carrier $(0.25 \mathrm{~g})$ was incubated in $10 \mathrm{ml}$ sodium bicarbonate buffer, $0.1 \mathrm{M}, \mathrm{pH} 8.5$, containing $0.05 \%(\mathrm{w} / \mathrm{v})$ dithiothreitol with $300 \mu \mathrm{l}$ enzyme solution (18 U/1 preparation) for 48 hours at room temperatures with stirring, and one incubation mixture contained additionally $1 \%(w / v)$ BSA .

Linkage on polyethylenglycol was carried out according to the method of Beauchamp et al.[17], treatment in anhydrous organic solvent according to the method of Volkov [18] and linkage to new carbohydrate-based materials according to the method of Wang et al.[19]; Aminoglucose (430 mg) + 230 methacryloylchloride $(90 \%$, $230 \mu \mathrm{l})$ were incubated in $10 \mathrm{ml}$ methanol at room temperature for $24 \mathrm{~h}$. After centrifugation and exctraction of the unreacted methacryloylchloride several times with methanol, the product was disolved in $7 \mathrm{ml} 0.2 \mathrm{M}$ tris buffer , $\mathrm{pH} 8$, and $30 \mu \mathrm{l} 45 \%$ ammonium persulphate was added. The mixture was degased $\left(\mathrm{N}_{2}\right)$ and incubated at $4^{\circ} \mathrm{C}$ for $72 \mathrm{~h}$. The polymer was ultrafiltered using an Amicon PM 1000 Da membrane and incubated with the enzyme in sodium borate buffer $0.2 \mathrm{M}, \mathrm{pH} 9$, in presence of $0.1 \mathrm{M} \mathrm{NaBH} 3 \mathrm{CN}$ at $37^{\circ} \mathrm{C}$ for $5 \mathrm{~h}$, followed by an incubation overnight at room temperature. After filtration in a centricon cell $(10 \mathrm{kDa})$, the solution was separated by gel filtration (Superose P12). 


\section{Results and Discussion}

\section{Enzyme purification}

The $\alpha$-glucosidase appeared to be extracellular; approximately $90 \%$ of the enzyme was found in the supernatant. The $\alpha$-glucosidase was purified 875 -fold with a yield of about $4 \%$ from the concentrated supernatant (table 1). The Superose P12 gel filtration was carried out at $\mathrm{pH} 6.8$ in presence of $0.05 \%$ dithiothreitol. When it was carried out at pH 6.3 and without dithiothreitol, the enzyme lost its activity overnight. The denaturation was irreversible, and changing the $\mathrm{pH}$ to 6.8 or 7.4 , addition of $1 \%$ dithiothreitol, concentration of the sample, or the addition of $1 \%$ BSA did not recover the activity, although the enzyme was active in a less purified state for several months at $\mathrm{pH}$ 6.3. In the Mono Q step carried out at $\mathrm{pH} 5.9$, eluted fractions were collected in

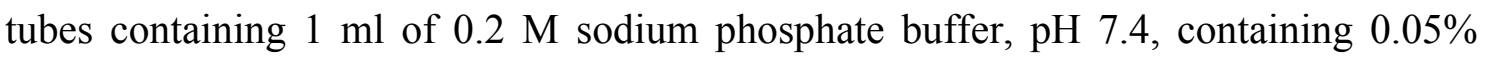
$(\mathrm{w} / \mathrm{v})$ dithiothreitol to prevent irreversible denaturation.

The data in table 1 were determined in the absence of dithiothreitol. It was subsequently found that addition of dithothreitol caused a large increase in activity (Table 3), which indicated the presence of oxidation-sensitive thiol group(s) on the enzyme. Given this, and the stimulation of the enzyme by BSA, it is possible that actual losses of enzyme during the purification are less than indicated by Table 3 .

The SDS/PAGE of the final preparation revealed a single band of a molecular weight of $120 \mathrm{kDa}$, which was identified as the $\alpha$-glucosidase by specific coloration of the band when incubating the gel in $40 \mathrm{mM}$ pNP- $\alpha-\mathrm{D}$-glucopyranoside solution, $\mathrm{pH}$ 7.4, at $90^{\circ} \mathrm{C}$ for $20 \mathrm{~min}$. Gel filtration on Superose 12 indicated a molecular mass of about $60 \mathrm{kDa}$. It is possible that hydrophobic interactions of the enzyme with the Superose column caused this low value. But incomplete unfolding of the protein on SDS treatment can cause a false molecular estimation also. As the enzyme is only readily denatured by SDS under conditions which might also lead to peptide bond hydrolysis (table 4 ), the molecular mass is not clear. 
(After freeze-drying the enzyme and running a SDS/PAGE, one strong band appeared at $60 \mathrm{KDa}$.)

The molecular mass of most microbial $\alpha$ - glucosidases are below $70 \mathrm{kDa}$ [2], however, $\alpha$-glucosidases of high molecular mass $(125,130$ and $140 \mathrm{kDa})$ have been reported in Aspergillus awamori [20] and in Pyrococcus furiosus [21] (125 kDa).

The isoeletric point was approximately 5 .

\section{pH optimum and pH stability}

Stability tests of the purified enzyme at different $\mathrm{pH}$ showed that in a dilute solution and below pH 6.8 the enzyme is inactivated at room temperature after 48 hours. This denaturation could be prevented by addition of $1 \%(\mathrm{w} / \mathrm{v})$ BSA in the incubation-mixture at $\mathrm{pH} 6.3$, but not at $\mathrm{pH} 5.9$ (Table 2). The enzyme in a less pure state is stable at $\mathrm{pH} 6.3$ for several months.

The $\mathrm{pH}$ optimum is above $\mathrm{pH} 7$ and no significant difference in activity was observed between $\mathrm{pH} 7$ and 8.5. A slightly acid $\mathrm{pH}$ optimum is a feature of other $\alpha$-glucosidases $[2,22,23]$.

\section{Inhibitors and activators}

The activity was tested in presence of some bivalent metal ions and other additives (Table 3). The effect of ethanol can be attributed to transferase activity, the ethanol acting as a suitable acceptor for this reaction. $\mathrm{Hg}^{2+}, \mathrm{Co}^{2+}, \mathrm{Ni}^{2+}$ inhibit the enzyme activity, which might be expected given the effect of dithiothreitol, probably on thiol groups. Treatment with the chelator EDTA results in increasing the activity of the enzyme presumably by removal of trace heavy metals, while the bivalent metal ions $\mathrm{Mg}^{2+}, \mathrm{Ca}^{2+}$ and $\mathrm{Zn}^{2+}$ slightly decrease the activity.

Table 4 shows that the enzyme is relatively unaffected by denaturing agents at $75^{\circ} \mathrm{C}$. Activities without preincubation were similar.

\section{Substrate specificity}

The $K_{\mathrm{m}}$ of the glucosidase for pNP- $\alpha$ D-glucopyranoside is $0.41 \mathrm{mM}$ using substrate concentrations of $<8 \mathrm{mM}$. $\mathrm{V}_{\max }$ is $182 \mathrm{U} / \mathrm{mg}$ enzyme at $75^{\circ} \mathrm{C}$ in sodium phosphate buffer, $0.2 \mathrm{M}, \mathrm{pH} 7.4$, containing $0.01 \%(\mathrm{w} / \mathrm{v})$ dithiothreitol. 
The enzyme had no activity on any of following substrates (tested at $4 \mathrm{mM}$ under standard assay conditions at $75^{\circ} \mathrm{C}$ and at $\mathrm{pH} 6.3$ ): pNP- $\beta-\mathrm{D}$-glucopyranoside, pNP- $\alpha-$

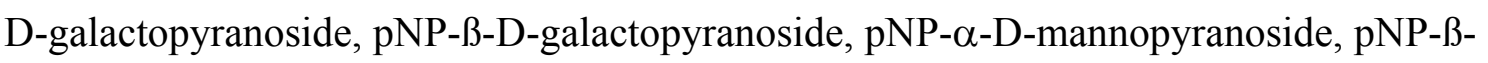
D-mannopyranoside, pNP- $\alpha$-D-fucopyranoside, pNP-ß-D-fucopyranoside, pNP- $\alpha$-Darabinopyranoside, pNP-ß-D-xylopyranoside, pNP-ß-D-lactopyranoside, pNP- $\alpha$-Drhamnopyranoside, $\mathrm{pNP}-\alpha-\mathrm{D}-\mathrm{maltoside}, \mathrm{pNP}-\beta-\mathrm{D}-\mathrm{maltoside}$.

Analysis on the sugar-Pak HLPC column revealed that Isomaltose (Glc $\alpha 1$ 6Glc), Maltose (Glc $\alpha 1-4 \mathrm{Glc}$ ), Nigerose (Glc $\alpha 1-3 \mathrm{Glc})$, Palatinose (Glc $\alpha 1-6 \mathrm{Fru}$ ), Turanose (Glc $\alpha 1-3$ Fru) and Panose (Glco1-6Glc $\alpha 1-4$ Glc) were hydrolysed. Table 5 shows the estimated specific activity on natural substrates compared to that on pNP- $\alpha-$ D-glucopyranoside. Surprisingly, the enzyme hydrolysed Panose, Palatinose and Nigerose at a higher rate than Maltose and Isomaltose.

No hydrolysis-products were detectable using $40 \mathrm{mM}$ maltotriose, maltotetraose, maltopentaose, maltohexaose, isomaltotriose, lactose (Gal $\beta 1-4 \mathrm{Glc})$, sucrose (Glc $\alpha 1$ $\beta$ Fru), raffinose (Gal $\alpha 1-6$ Glc $\alpha 1-2 \beta F r u)$, trehalose (Glc $\alpha-\alpha^{\prime}$ Glc), cellobiose (Glc $\beta 1$ 4Glc), $\beta$-gentobiose (Glc $\beta 1-6 \mathrm{Glc}$ ), melizitose (Glc $\alpha 1-3 \beta$ Fru2-1 $\alpha \mathrm{Glc}$ ), melibiose (Gal $\alpha 1-6 \mathrm{Glc})$, or 1\% (w/v) starch, amylose, dextran, amylopectin ( $\alpha 1-4 \mathrm{Glc} \alpha 1-6)$, pullulan ( $\beta 1-6$ maltotriose), inulin , or pectin after 50 hours incubation, using $0.34 \mu \mathrm{g}$ enzyme in $100 \mu \mathrm{l}$ at $75^{\circ} \mathrm{C}$, $\mathrm{pH} 7.4$.

Each sugar (concentrations up to $60 \mathrm{mM}$ ) was treated as a competitve inhibitor of pNP$\alpha$-D-glucopyranoside. The inhibitor constants $K_{\mathrm{i}}$ are shown in Table 5. Inhibitor concentrations were 30 and $60 \mathrm{mM}$ maltose, $60 \mathrm{mM}$ isomaltose, $30 \mathrm{mM}$ panose, $5 \mathrm{mM}$ nigerose, $60 \mathrm{mM}$ cellobiose, 30 and $60 \mathrm{mM}$ palatinose and turanose. Compared to the $K_{\mathrm{m}}$ for the substrate $\mathrm{pNP}-\alpha-\mathrm{D}$-glucopyranoside the $K_{\mathrm{i}}$ values are relatively high for the substrates isomaltose $(14 \mathrm{mM})$ and maltose $(15.6 \mathrm{mM})$.

The values from the table 5 allowed the estimation of substrate preference, pNP- $\alpha$ glucoside $>$ nigerose $($ Glc $\alpha 1-3$ Glc) $>$ palatinose (Glc $\alpha 1-6$ Fru) $>$ panose (Glco16 Glc $\alpha 1-4 \mathrm{Glc})>$ isomaltose $(\mathrm{Glc} \alpha 1-6 \mathrm{Glc})>$ maltose $(\mathrm{Glc} \alpha 1-4 \mathrm{Glc})>$ turanose $(\mathrm{Glc} \alpha 1-$ 3Fru). 
The $\alpha$-glucosidase is distinct from other thermophilic $\alpha$-glucosidases in its substrate specificity, showing a high hydrolytic activity towards pNPGand a preference order of $\alpha 1-3>\alpha .>\alpha 1-4$ in glucose driers.

The thermostable $\alpha$-glucosidase from Clostridium thermohydrosulfuricum 39E also showed higher rates of hydrolysis of panose and turanose than for maltose or isomaltose [24]. The purified $\alpha$-glucosidase from Pyrococcus furiosus had highest activity towards maltose and isomaltose and lower activity toward pNP-glucoside [21].

\section{Temperature effects}

An Arrhenius plot of $\log$ (initial rection velocity) against the reciprocal of temperature at $\mathrm{pH} 6.3$ was linear below $105^{\circ} \mathrm{C}$. The activation energy $(\mathrm{Ea})$ of the enzyme as calculated from the Arrhenius plot is $73 \mathrm{~kJ} / \mathrm{mol}$.

Plots of log remaining activity against incubation time were linear. The halflives of the enzyme at $98^{\circ} \mathrm{C}$ were $\mathrm{t}_{1 / 2}<40 \mathrm{~min}$ in buffer; with added $1 \%(\mathrm{w} / \mathrm{v})$ dithiothreitol $\mathrm{t}_{1 / 2}<150 \mathrm{~min}$; with $1 \%(\mathrm{w} / \mathrm{v})$ BSA $\mathrm{t}_{1 / 2}<90 \mathrm{~min}$; and with both $1 \%$ $(\mathrm{w} / \mathrm{v})$ dithiothreitol and $1 \%(\mathrm{w} / \mathrm{v})$ BSA $\mathrm{t}_{1 / 2}<215 \mathrm{~min}$, all in sodium phosphate buffer $0.2 \mathrm{M}, \mathrm{pH}$ 7.4. These half-lives were dependant on the conditions employed $(\mathrm{pH}$, ionic strength, enzyme concentration) and cannot be extrapolated to other conditions. Studies of the half-lives of the enzyme from the crude material gave values of $>60 \mathrm{~min}$ at $95^{\circ} \mathrm{C}$ and $>20 \mathrm{~min}$ at $103^{\circ} \mathrm{C}$ [24]. On purification, the enzyme became much less thermostable, although this seems to be due to oxidation and low protein concentration.

\section{Enzyme stabilization}

Enzyme was immobilized on to various matrices, including carbohydrates, and by crosslinking. In all cases except crosslinking (20\% recovery) more than $40 \%$ of the original activity was recovered.Table 6 shows the $K_{\mathrm{m}}$ 's of the immobilized enzyme.

Of the various covalent modifications tried none enhanced stability significantly except linkage to carbohydrate-based material (Table 7).

A number of additives enhanced stability. Sorbitol was particularily successful, as found previously [], raising the half life by more than an order of magnitude (Table 7). 
Dithiothreitol and BSA had even more dramatic effect, the former presumably by stabilising sulphydryl groups; the effect of these with sorbitol was additive (Figure 1). Although the carbohydrate-immobilized enzyme was the most stable of the covalent modifications, additives did not further enhance stability. The only case where the use of an additive with a covalently modified enzyme increased stability significantly over use of the additive alone was the epoxy-bead-linked (or oxirane acrylic bead-linked) and the cocrosslinked enzyme with $90 \%$ (w/v) sorbitol, which had half lives of 20-60 min at $130^{\circ} \mathrm{C}$ (Table 7, Fig.1 and 2). The stabilized enzyme exhibited the higher activity expected at $130^{\circ} \mathrm{C}$ compared with $100^{\circ} \mathrm{C}$ (Fig.3).

None of these techniques (Table 7) stabilized the enzyme at $140^{\circ} \mathrm{C}$. In all cases all activity was lost after incubation of the enzyme for $5 \mathrm{~min}$ at $140^{\circ} \mathrm{C}$.

Overall, it has been possible to raise the half-life of the $\alpha$-glucosidase from about 5 min at $110^{\circ} \mathrm{C}$ to about $60 \mathrm{~min}$ at $130^{\circ} \mathrm{C}$, by the additive effects of immobilization and sorbitol, corresponding to an increase in half life at a given temperature of between 2 and 3 orders of magnitude. This clearly indicates that not only is the enzyme conformationally stabilised at $130^{\circ} \mathrm{C}$, but is also stabilized against degradation reactions: as suggested by Hensel [], conformational stabilization may confer resistance to degradation. In any event, there is no reason to suppose that the application of these techniques to more stable enzymes will not raise stabilities still further, nor that $130^{\circ} \mathrm{C}$ is the upper temperature limit for protein stability. 


\section{References}

[1] Kelly, C.T. and Fogerty, W.M. (1983) Process Biochem. 18, 6-12

[2] Fogerty, W.M. and Kelly, C.T. (1979) Prog.Ind.Microbiol. 15, 87-151

[3] Plant A.R., Parrat S. Daniel, R.M.and Morgan, H.W. (1988) Biochem. J. 255,865868

[4] Consalvi, V et al.(1991) Eur.J. Biochem. 196, 459-467

[5] Hudson R.C., Ruttersmith and Daniel R.M. (1993) BBA, 1202, 244-250

[6] Klibanov A.M., (1983), Advances in applied Microbiology, 29, 1-28

[7] Klibanov A.M, (1979), Anal. Biochemistry, 93, 1-25

[8] Mozhaev V. V. and Martinek K., (1984), Enzym. Microbiol. Technol., 51-59

[9] Bradford M.M. (1976), Anal. Biochem. 72, 248

[10] Broun G.B, Methods of Enzymology (1976), 44, 268-270

[11] Stolzenbach F E., Dixon J., BBRC, 52, 3, 1973, 905

[12] Broun G.B., Methods of Enzymology (1976), 44, 263-266

[13] Stolzenbach F.E. and Kaplan N.O.(1976) Methods in Enzymology 44, 929-932

[14] Dixon J., Stolzenbach F.E., Berenson J.A., Kaplan N.O., (1973), BBRC 52, No.3, 905912

[15] Methods of Enzymology, Vol 44, 34 epoxy solomon

[16] Methods of Enzymology, OAB]

[17] PEG, Methods of Enzymology, Beauchamp et al.

[18] Klinaov A.M.(1991), Biotechn. and Bioeng. 37, 843-853

[19] Wang P, et al., (1992) J.Am. Chem.Soc., 114, 378-380,

[20] Kelly C.T. + Fogerty W.M., 1983 Process. Biochem. 18, 6-12

[21] Constantino H.R., Brown S.H.and Kelly R. M. (1990), 172, No.7, 3654-3660

[22] Saha B.C. and Zeikus J. G.(1991) Appl.Microbiol. Biotechn., 35, 568-571.

[23] Yamasaki Y., Suzuki V.and Ozawa, J. (1977)., 41, 2140-2161

[24] Suzuki, M. Tsuji, T. and Abe, S. 1976, Appl. Environ. Microbiol., 32, 747-752 
Table 1: Purification of the $\alpha$-glucosidase from Thermococcus strain AN1.

\begin{tabular}{|c|c|c|c|c|c|c|c|}
\hline \multirow{2}{*}{$\begin{array}{l}\text { step } \\
\text { conc. supernatant }\end{array}$} & \multirow{2}{*}{$\begin{array}{l}\text { total activity } \\
100 \mathrm{U}\end{array}$} & \multicolumn{4}{|c|}{ protein spec.Activity purification } & \multicolumn{2}{|l|}{ yield } \\
\hline & & $2500 \mathrm{mg}$ & 0.0 & $\mathrm{~J} / \mathrm{mg}$ & 1 & & $100 \%$ \\
\hline Hiload Q Sepharose & $54 \mathrm{U}$ & $600 \mathrm{mg}$ & 0.0 & $\mathrm{~J} / \mathrm{mg}$ & 2.3 & & $54 \%$ \\
\hline Phenyl Sepharose & $30 \mathrm{U}$ & $24 \mathrm{mg}$ & 1.2 & $\mathrm{~J} / \mathrm{mg}$ & 31 & & $30 \%$ \\
\hline HPHT & $4.18 \mathrm{mg}$ & 4.8 & $\mathrm{mg}$ & 120 & & $20 \%$ & \\
\hline Superose P12 & $11.5 \mathrm{U} 0.4 \mathrm{mg}$ & $28.7 \mathrm{U} / \mathrm{mg}$ & 71 & & $11 \%$ & & \\
\hline Mono Q & $4 \mathrm{U}$ & $0.05 \mathrm{mg}$ & & $\mathrm{mg}$ & 875 & & $4 \%$ \\
\hline
\end{tabular}

Activity was determined in Mes-buffer $0.1 \mathrm{M}, \mathrm{pH} 6.3$ using pNP $\alpha$-glucoside as substrate at $75^{\circ} \mathrm{C}$. 
Table 2: Activity of the $\alpha$-glucosidase in different buffers at $\mathrm{pH} 5.9,6.3$, and $\mathrm{pH} 6.8$

\begin{tabular}{llll}
\hline buffer & A (19h) & B (48h) & C (48h, 1\% (w/v) BSA) \\
\hline Mes 0.2M, pH 6.3 & $100 \%$ & $0 \%$ & $100 \%$ \\
bis Tris 0.2M, pH 6.3 & $91 \%$ & $0 \%$ & $100 \%$ \\
bis Tris 0.2M, pH 5.9 & $40 \%$ & $0 \%$ & $12 \%$ \\
sodium phosphate 0.2M pH 6.8 & $100 \%$ & $100 \%$ & $100 \%$ \\
\hline
\end{tabular}

Activity of the $\alpha$-glucosidase in different buffers at $\mathrm{pH} 5.9,6.3$, and $\mathrm{pH} 6.8$ was compared with the activity in presence of $1 \%(\mathrm{w} / \mathrm{v})$ BSA. A: remaining $\alpha$-glucosidase activity after prior incubation of the enzyme in buffer at room temperature during 19 hours; B: after 48 hours incubation, C: after 48 hours incubation in presence of $1 \%$ (w/v) BSA. 
Table3: Activity of the a-glucosidase in presence of metal ions and other additives.

\begin{tabular}{ll}
\hline Additive & Mops buffer $(0.2 \mathrm{M}, \mathrm{pH} 7)$ \\
\hline- & $100 \%$ \\
$\mathrm{DTT}, 1 \%(\mathrm{w} / \mathrm{v})$ & $170 \%$ \\
$\mathrm{BSA}, 4 \%(\mathrm{w} / \mathrm{v})$ & $250 \%$ \\
$\mathrm{EDTA}, 1 \mathrm{mM}$ & $146 \%$ \\
$\mathrm{CaCl}_{2}, 3 \mathrm{mM}$ & $57 \%$ \\
$\mathrm{MgCl}_{2}, 3 \mathrm{mM}$ & $87 \%$ \\
$\mathrm{ZnCl}_{2}, 3 \mathrm{mM}$ & $37 \%$ \\
$\mathrm{MnCl}_{2}, 3 \mathrm{mM}$ & $57 \%$ \\
$\mathrm{HgCl}_{2}, 3 \mathrm{mM}$ & $0 \%$ \\
$\mathrm{FeCl}_{2}, 1 \mathrm{mM}$ & $182 \%$ \\
$\mathrm{CoCl}_{2}, 3 \mathrm{mM}$ & $4 \%$ \\
$\mathrm{NiCl}_{2}, 3 \mathrm{mM}$ & $7 \%$ \\
$\mathrm{CuCl}_{2}, 3 \mathrm{mM}$ & $57 \%$ \\
$\mathrm{CdCl}_{2}, 3 \mathrm{mM}$ & $65 \%$ \\
$\mathrm{Ethanol}_{2}, 20 \%$ & $196 \%$ \\
\hline
\end{tabular}

Enzyme was incubated in presence of the additives for 1 hour at room temperature prior to measuring the remaining activity. Triton-X-100 1\%, $\mathrm{NaCl} 5 \%, \mathrm{AgCl} 1 \mathrm{mM}$, ammonium sulfate $2.4 \%(\mathrm{w} / \mathrm{v})$ had no effect on the enzyme activity.. 
Table 4: Effect of denaturing agents on the enzyme activity

\begin{tabular}{ll}
\hline denaturing agent & 1 hour preincubation \\
\hline buffer, pH 7.4 & $100 \%$ \\
$2 \%(w / v)$ SDS & $116 \%$ \\
$1 \%(w / v)$ SDS & $121 \%$ \\
$8 \mathrm{M}$ urea & $43 \%$ \\
$4 \mathrm{M}$ urea & $73 \%$ \\
\hline
\end{tabular}

Activity of the enzyme in presence of urea and SDS in sodium phosphate buffer at $\mathrm{pH}$ 7.4 at $75^{\circ} \mathrm{C}$. Preincubation was at room temperature. 
Table 5: Specific activity of the enzyme and Inhibitor Constants.

\begin{tabular}{|c|c|c|c|}
\hline Substrate & Specific activity & $K_{\mathrm{m}} \quad$ or & $K_{\mathrm{i}}$ \\
\hline pNP- $\alpha$-D-glucoside & $22 \mathrm{U} / \mathrm{mg}$ & $0.41 \mathrm{mM}$ & \\
\hline Nigerose & $2 \mathrm{U} / \mathrm{mg}$ & & $2 \mathrm{mM}$ \\
\hline Panose & $3.4 \mathrm{U} / \mathrm{mg}$ & & $13 \mathrm{mM}$ \\
\hline Palatinose & $1.53 \mathrm{U} / \mathrm{mg}$ & & $11 \mathrm{mM}$ \\
\hline Isomaltose & $1 \mathrm{U} / \mathrm{mg}$ & & $14 \mathrm{mM}$ \\
\hline Turanose & $0.4 \mathrm{U} / \mathrm{mg}$ & & $17 \mathrm{mM}$ \\
\hline Maltose & $0.26 \mathrm{U} / \mathrm{mg}$ & & $15.6 \mathrm{mM}$ \\
\hline Cellobiose & $0 \mathrm{U} / \mathrm{mg}$ & & $30 \mathrm{mM}$ \\
\hline
\end{tabular}

Table 5:

Enzyme specific activity was estimated by analysis of end products on a sugar PAK HPLC column.

Substrate concentration used were from 0.2 to $8 \mathrm{mM}$ pNP- $\alpha$-D-glucopyranoside, and 40 $\mathrm{mM}$ for other substrates. Assays were carried out in sodium phosphate buffer $0.2 \mathrm{M}, \mathrm{pH}$ 7.4, containing $0.01 \%(\mathrm{w} / \mathrm{v})$ dithiothreitol at $75^{\circ} \mathrm{C}$. The enzyme concentration was 0.08 $\mu \mathrm{g}$ per assay. Inhibitor concentrations of up to $60 \mathrm{mM}$ were used. 
Table 6: Comparision of the $K_{\mathrm{m}}$ of the free and immobilized enzyme.

\begin{tabular}{ll}
\hline Immobilization on to & $K_{\mathrm{m}}$ \\
\hline Free enzyme & $0.41 \mathrm{mM}$ \\
Oxirane acrylic beads & $0.56 \mathrm{mM}$ \\
Epoxy-Carrier & $3 \mathrm{mM}$ \\
Alkylamino glass beads & $8.6 \mathrm{mM}$ \\
Uncoated controlled glass beads & $8.2 \mathrm{mM}$ \\
Co-crosslinked enzyme & $0.71 \mathrm{mM}$ \\
\hline
\end{tabular}

$\mathrm{Km}$ comparision of immobilized enzyme at $\mathrm{pH} 6.8$, at $75^{\circ} \mathrm{C}$ with $\mathrm{pNP}-\alpha$-glucoside as substrate. 
Table 7: Half-lives of the free and stabilized enzyme at 110,120 and $130^{\circ} \mathrm{C}$.

\section{stabilization techniques}

Enzyme, Mes buffer, pH 6.3

Enzyme, sodium phosphate buffer, $\mathrm{pH} 7.4$

Glass Beads-enzyme (all sizes), pH 6.3

Alkylamine glass beads-enzyme, $\mathrm{pH} 6.3$

Oxirane acrylic beads/ epoxy beads-enzyme, $\mathrm{pH} \sim 5$

6.3

Crosslinked Enzyme, $\mathrm{pH} 6.3$ or $\mathrm{pH} 7.4$

Co-cross linked enzyme, $\mathrm{pH} 6.3$ or $\mathrm{pH} 7.4$

PEG-enzyme, $\mathrm{pH} 6.3$

Carbohydrate-enzyme, pH 6.3

$13 \%$ ammonium sulfate, $\mathrm{pH} 6.3$

$53 \%$ ammonium sulfate, $\mathrm{pH} 6.3$

90\% sorbitol, $\mathrm{pH} 6.3$

$99 \%$ sorbitol, $\mathrm{pH} 6.3$

$90 \%$ inositol, $\mathrm{pH} 6.3$

$50 \%$ trehalose, $\mathrm{pH} 6.3$

$90 \%$ trehalose, $\mathrm{pH} 6.3$

90\% glycerol, $\mathrm{pH} 6.3$

$90 \%$ sorbitol, $\mathrm{pH} 7.4$

90\% sorbitol, 1\% DTT, pH 7.4

$90 \%$ sorbitol, $1 \%$ BSA, pH 7.4

90\% sorbitol , 1\% DTT, 1\% BSA, pH 7.4

$104.9 \mathrm{~nm}$ glass beads $+53 \%\left(\mathrm{NH}_{4}\right) 2 \mathrm{SO}_{4}$

$104.9 \mathrm{~nm}$ glass beads $+90 \%$ sorbitol

$104.9 \mathrm{~nm}$ glass beads $+50 \%$ trehalose

Alkylamino glass beads $+53 \%\left(\mathrm{NH}_{4}\right)_{2} \mathrm{SO}_{4}$

Alkylamino glass beads $+50 \%$ trehalose

Alkylamino glass beads $+90 \%$ sorbitol

OAB, pH 7.4, + 90\% Sorbitol

OAB, pH 7.4, 90\% sorbitol , 1\% BSA

OAB (linkage with E+BSA) , $\mathrm{pH} 7.4,90 \%$

Sorbitol

E+ 90\% sorbitol, $\mathrm{pH} 6.8 *$

Epoxy-carrier, pH 6.8, 90\% sorbitol*

Carbohydrate-Enzyme $+90 \%$ sorbitol, $\mathrm{pH} 6.3$

PEG M20 or 4000-Enzyme+ 90\% sorbitol, pH 6.3

Cocrosslinked enzyme $+53 \%\left(\mathrm{NH}_{4}\right)_{2} \mathrm{SO}_{4}$

Cocrosslinked enzyme $+50 \%$ trehalose

Cocrosslinked enzyme $+90 \%$ sorbitol, $\mathrm{pH} 6.3 / 7.4$

\section{$t_{1} / 2$ at $110^{\circ} \mathrm{C} \quad t_{1} / 2$ at $120^{\circ} \mathrm{C} \quad t_{1} / 2$ at $130^{\circ} \mathrm{C}$}

$\begin{array}{lll}\sim 5 & <2 & <1 \\ \sim 5 & <2 & \end{array}$

$\sim 5$

$\sim 5$

$\sim 3$

$\sim 8$

$\sim 5$

$\sim 20$

$\sim 13$

$\sim 165$

$<2$

$\sim 120$

$\sim 23$

$\sim 60$

$<5$

$\sim 60$

$\sim 5$

$\sim 30$

$>60 \sim 26$

$\sim 3$

$\sim 415$

540

500

$>>600$

$<5$

$>>100 \quad \sim 30 \quad<2$

$>100 \sim 18$

$\sim 70$

$\sim 55 \sim 25$

$\sim 35 \sim 40$

$>60 \sim 60$

$\sim 20$

$\sim 30$

$\sim 40$

76

180

$15 \sim 10\left(125^{\circ} \mathrm{C}\right)<2\left(130^{\circ} \mathrm{C}\right)$

$25 \sim 20\left(125^{\circ} \mathrm{C}\right) \sim 6\left(130^{\circ} \mathrm{C}\right)$

$>5 \quad \sim 5$

$\sim 20$

$\sim 120$

$\sim 90$
$<6$

$<15$

$\sim 30$

$>30$

$<2$

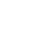

$>120(\mathrm{pH} \mathrm{6.3)} \quad \sim 90(\mathrm{pH} 6.3) \quad \sim 60(\mathrm{pH} 7.4)$ 
Table 8: half-lives at the indicated temperatures compared with the half-lives of the enzyme without stabilization. E; Enzyme, OAB: oxirane acrylic beads, PEG: polyethylenglycol, DTT: dithiothreitol, $\%$ is $\%(\mathrm{w} / \mathrm{v})$ unless otherwise mentioned.

Following additives did not enhance the stability at $110^{\circ} \mathrm{C}$ (or only very slightly): $99 \%(\mathrm{v} / \mathrm{v})$ butanol, a mixture of butanol/water $(7: 3)$, of nonane/water $(7: 3), 10 \%$ polyvinylpyrrolidone 40 ( $\sim 8 \mathrm{~min}), 20 \%$ PEG M20 ( 8 min) , 30\% PEG $4000(\sim 10$ $\min$ ), 40\% PEG 300 ( $9 \mathrm{~min}), 1 \mathrm{M} \mathrm{NaCl}$ ( $<10 \mathrm{~min}), 10 \%$ Triton $\mathrm{X}-100$ ( $\sim 5 \mathrm{~min}), 0.05$ or $0.5 \%$ ( v/v) DMSO ( $<5 \mathrm{~min}), 90 \%$ (v/v) ethanol ( $<5 \mathrm{~min}), 1 \%(\mathrm{w} / \mathrm{v})$ BSA $(<8 \mathrm{~min})$, $1 \%(\mathrm{w} / \mathrm{v})$ DTT $(<8 \mathrm{~min}), 1 \mathrm{mM}$ EDTA $(<5 \mathrm{~min}), 20 \%(\mathrm{v} / \mathrm{v})$ ethanol $(<7 \mathrm{~min})$, OAB enhancestability as much as epoxy beads, crosslinked enzyme $+90 \%$ sorbitol did not enhance stability further., Cocrosslinked enzyme contained $0.05 \%$ DTT. 
Figure 1: Stability of the $\alpha$-glucosidase at 110 and $130^{\circ} \mathrm{C}$.

Stability at $110^{\circ} \mathrm{C}$

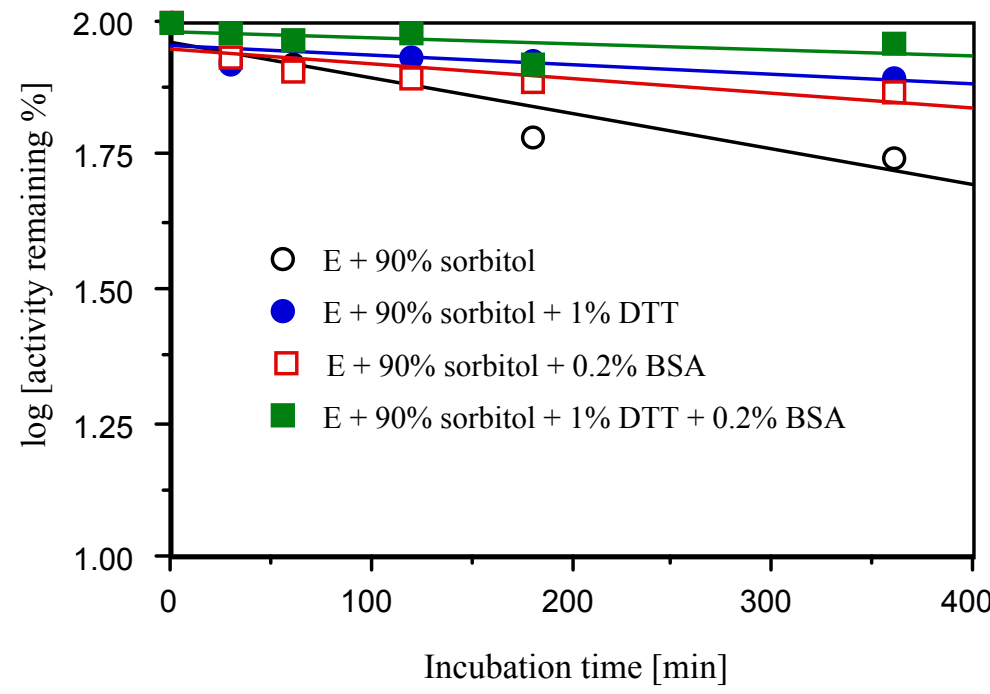

Stability at $130^{\circ} \mathrm{C}$

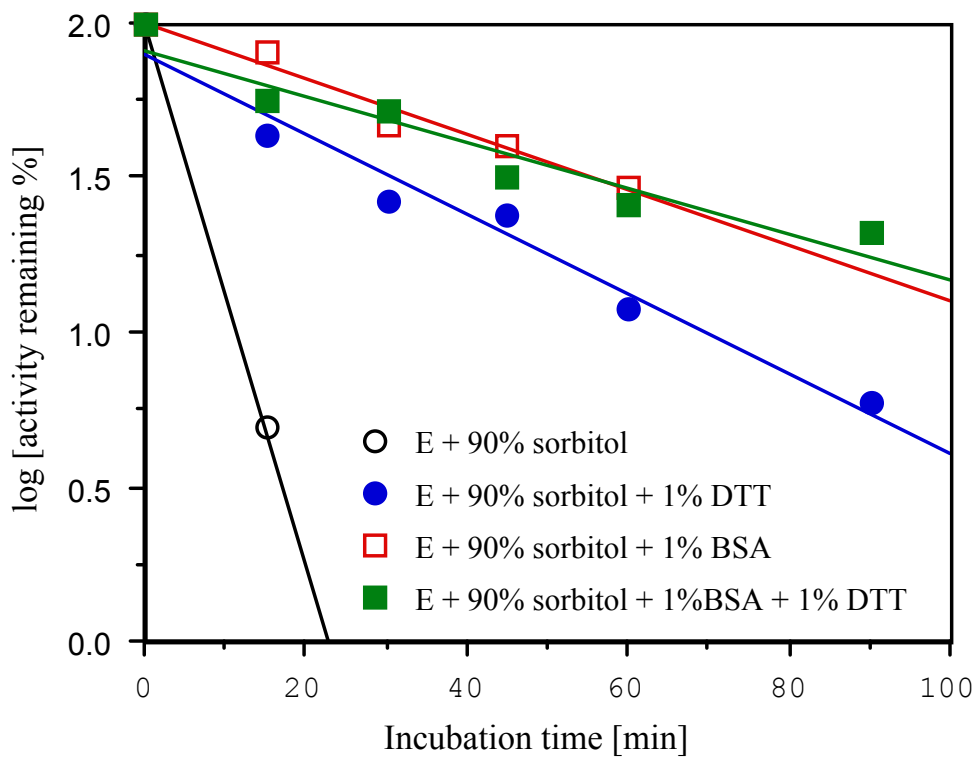


Figure 2: Stability of the free and epoxy-immobilized enzyme at 110,125 and $130^{\circ} \mathrm{C}$.
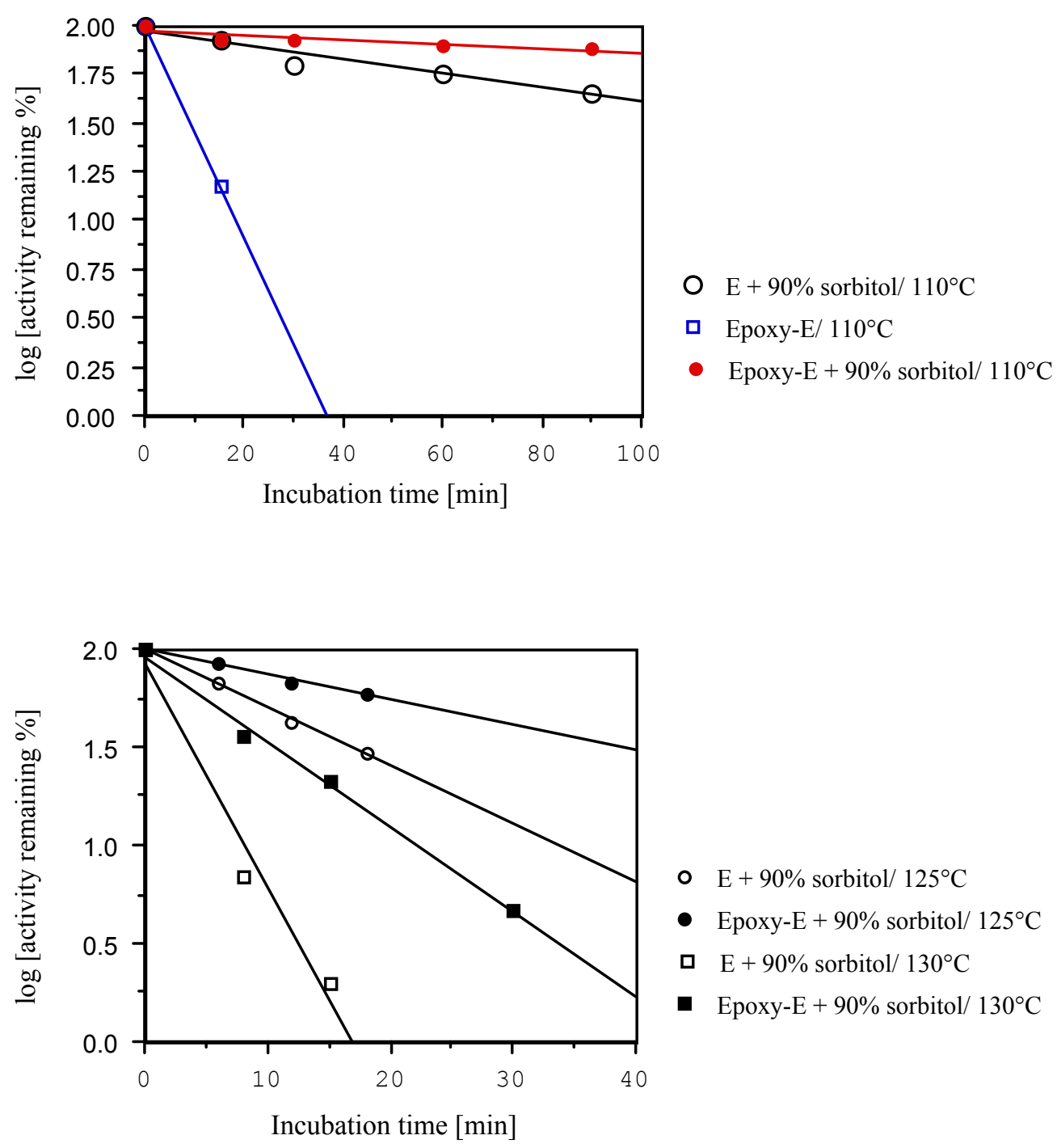
Figure 3: $\alpha$-glucosidase activity at $110^{\circ} \mathrm{C}$ and at $130^{\circ} \mathrm{C}$ in sodium phosphate buffer, $0.2 \mathrm{M}, \mathrm{pH} 7.4$.

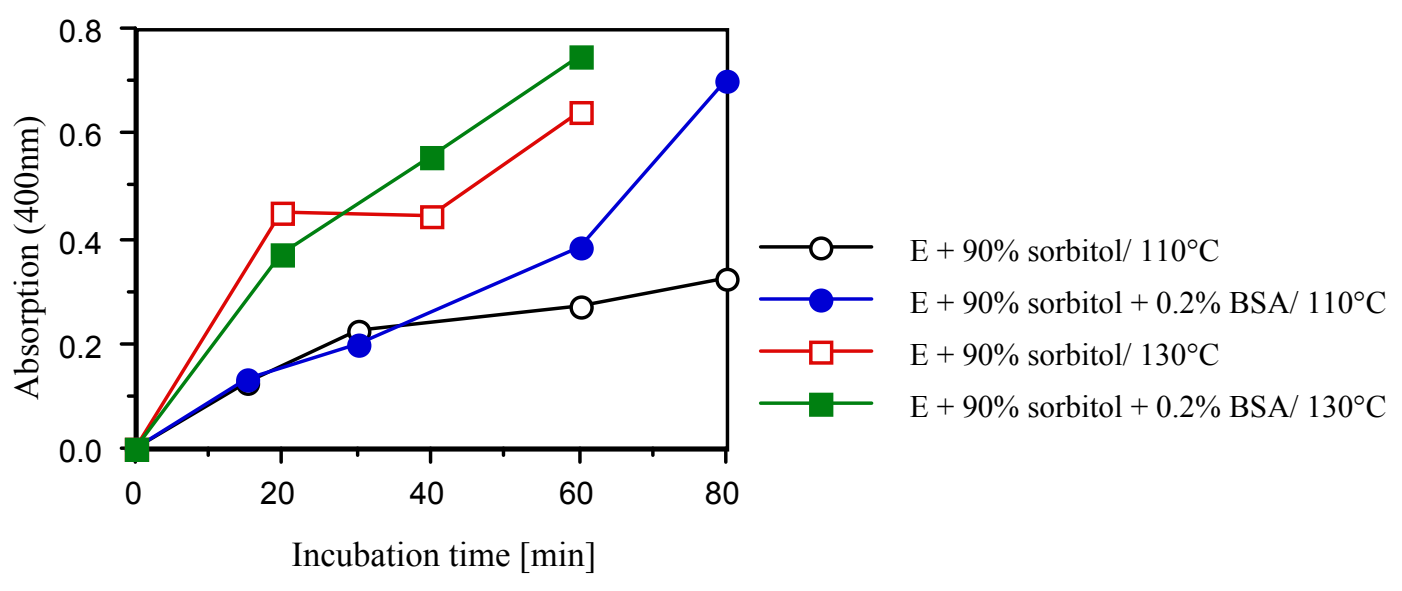

